\title{
A MONTAGEM DE HEARTFIELD NA GUERRA IDEOLÓGICA ÀS VÉSPERAS DA ASCENSÃO NAZISTA NA ALEMANHA ${ }^{1}$
}

Pollyana Ferreira Rosa ${ }^{2}$

\begin{abstract}
RESUMO: Nos últimos anos da República de Weimar, o fotojornalismo moderno e suas composições de imagens eram consumidas em massa por meio das revistas ilustradas. $\mathrm{O}$ fato de a aparência mimética da fotografia dar credibilidade aos textos não tardou a chamar a atenção de críticos de esquerda, observando que essa operação permitia a manipulação ou falseamento da realidade. Observaram-no também os líderes nazistas, que souberam utilizar tais características a seu favor. As montagens de Heartfield nas páginas da revista AIZ (Revista Ilustrada dos Trabalhadores) buscavam, segundo propomos, enfrentar essa questão. Sua estratégia consistiria em expor o caráter construído da fotografia por meio de operações que podem ser descritas enquanto estranhamentos que promovam distanciamento crítico (nas definições de Brecht) no leitor: pelo cômico/absurdo da fotomontagem-caricatura e por desmascarar os mecanismos de manipulação da leitura de composições de imagens. No entanto, a esquerda ligada ao Partido Comunista Alemão - como era o caso da revista AIZ, ainda que não explícito - subestimou o movimento nacional-socialista até quase às vésperas de sua ascensão ao poder. Veremos aqui algumas cenas dessa guerra ideológica.
\end{abstract}

Palavras-chave: fotomontagem; caricatura; fotojornalismo; arte política; antifascismo.

\section{HEARTFIELD'S MONTAGE IN THE IDEOLOGICAL WAR ON THE EVE OF THE NAZI RISE IN GERMANY}

\begin{abstract}
In the last years of the Weimar Republic, modern photojournalism and its compositions of images were massive consumed by means of illustrated magazines. The fact that the mimetic appearance of photography gave credibility to the texts soon attracted the attention of critics of the left, observing that this operation allowed the manipulation or falsification of reality. The Nazi leaders, who knew how to use such characteristics in their favor, also observed it. The Heartfield's 'montages' on the pages of AIZ magazine (Workers' Illustrated Magazine) sought, as we propose, to deal with this issue. His strategy would be to expose the constructed character of photography through operations that can be described as estrangement effect that promote distancing effect (in Brecht's definitions) in the reader: by the comic / absurdity of photomontage-caricature and by unmasking the mechanisms of manipulation on reading of image compositions. However, the left linked to the German Communist Party - like the AIZ magazine, although it was not explicit - underestimated the national-socialist movement until almost on the eve of its rise to power. We will see here some scenes of this ideological war.
\end{abstract}

KEYWORDS: photomontage; caricature; photojournalism; politic art; antifascism.

\footnotetext{
${ }^{1}$ Pesquisa parcialmente financiada pelas agências de fomento FAPESP e CAPES.

${ }^{2}$ Mestra em Artes Visuais pela Universidade de São Paulo (ECA-USP). Jornalista, fotógrafa e artista gráfica. Pesquisadora independente em artes, comunicação e história.
} 


\section{EL MONTAJE DE HEARTFIELD EN LA GUERRA IDEOLÓGICA A LAS VÍSPERAS DE LA ASCENSIÓN NAZISTA EN ALEMANIA}

RESUMEN: En los últimos años de la República de Weimar, el fotoperiodismo moderno y sus composiciones de imágenes eran consumidas en masa por medio de las revistas ilustradas. El hecho de que la apariencia mimética de la fotografía concede credibilidad a los textos no tardó en llamar la atención de críticos de izquierda, observando que esa operación permitía la manipulación o falseamiento de la realidad. Lo observaron también los líderes nazis, que supieron utilizar tales características a su favor. Las montajes de Heartfield en las páginas de la revista AIZ (Revista Ilustrada de los Trabajadores) buscaban, según planteamos, enfrentar esta cuestión. Su estrategia consistiría en exponer el carácter construido de la fotografía por medio de operaciones que pueden ser descritas como no conocidas y que promuevan distanciamiento crítico (en las definiciones de Brecht) en el lector: por el cómico / absurdo de la fotomontaje-caricatura y por desenmascarar los mecanismos de manipulación de la lectura de composiciones de imágenes. Sin embargo, la izquierda ligada al Partido Comunista Alemán -como era el caso de la revista AIZ, todavia no explícito - subestimó el movimiento nacionalsocialista hasta casi las vísperas de su ascensión al poder. Veremos aquí algunas escenas de esa guerra ideológica.

Palabras clave: fotomontaje; caricatura; fotoperiodismo; arte político; antifascismo.

\section{INTRODUÇÃO}

A duas semanas das eleições para o Reichstag, marcadas para 31 de julho de 1932, a publicação de esquerda AIZ (Arbeiter Illustrierte Zeitung - Revista Ilustrada dos Trabalhadores), de grande circulação, levou a público mais uma capa ${ }^{3}$ do artista gráfico John Heartfield ${ }^{4}$ (1891-1968) (Fig. 1). Nesta imagem, publicada no contexto do crescimento do nazismo como movimento de massas, o artista apresentava duas imagens em confronto, cujas similaridades na composição - a simetria da montagem, o enquadramento das fotos quase idêntico - fortaleciam o contraste entre seus conteúdos.

De um lado, vemos o príncipe da Prússia August Wilhelm (1887-1949) vestindo uniforme militar e uma braçadeira com a suástica, em pose de saudação nazista. Do outro, observamos um trabalhador desempregado, de muletas - não tem uma das pernas -, com a

\footnotetext{
${ }^{3}$ Infelizmente, não foi ainda possível ter acesso à revista, apenas a esta reprodução que impede identificação das pequenas fotos e das legendas. Baseio-me, aqui, nas descrições da historiadora estadunidense Lavin (2001), que teve acesso à referida revista.

${ }^{4}$ Nascido Helmut Herzfelde, o artista - um dos artífices do dadaísmo berlinense - anglicizou seu nome em 1916, como protesto contra o nacionalismo imperialista alemão.
} 
mão estendida, a mesma levantada pelo príncipe, a pedir esmolas na rua. Acima das imagens, lemos a pergunta: "Príncipe e trabalhador em um mesmo partido?".

A contraposição entre as fotografias do príncipe, em traje militar com a suástica nazista, e a do trabalhador de muletas, parece, à primeira vista, remeter à traumática memória coletiva da Primeira Guerra Mundial, que deixara muitos milhares de mutilados. O tema do soldado mutilado, aliás, apareceu de modo recorrente em gravuras produzidas por artistas alemães durante a guerra e no período da República de Weimar (1918-1933). Os desenhos de Georg Grosz (1893-1959), por exemplo, publicados em brochuras e revistas poucos anos após o fim do conflito, traziam insistentemente homens mutilados ${ }^{5}$ de modo a expor a oposição à guerra e ao militarismo e imperialismo prussianos.

Figura 1 - Capa da AIZ 11, n. 29

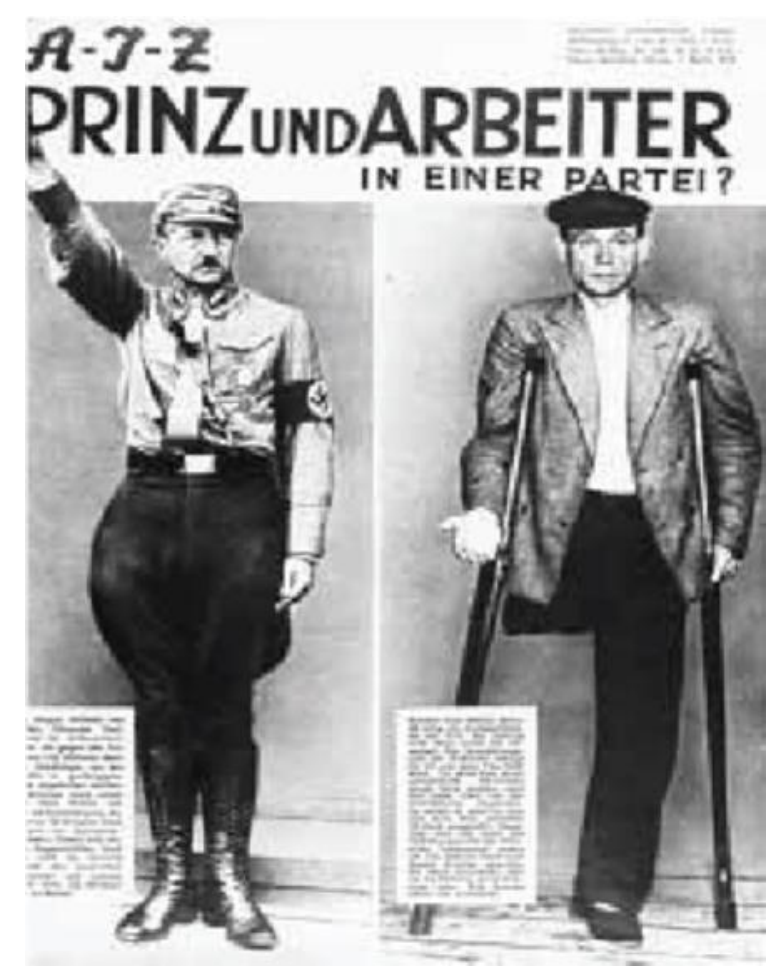

Fonte: LAVIN, 1985, p. 91

Desse modo, o confronto entre príncipe e trabalhador, colocado diante da pergunta se deveriam estar no mesmo partido, parece apontar mais diretamente para a oposição entre o

\footnotetext{
${ }^{5}$ Vale dizer que tal relação entre mutilados e o terror da guerra real era recorrente nas artes gráficas da modernidade: em Os Horrores da Guerra, série de gravuras publicada por Francisco de Goya (1746-1828) nos primeiros anos do século XIX, vemos figurados não apenas mutilados como sua imagem mais radical e desumanizadora: homens esquartejados.
} 
aristocrata imperialista e o trabalhador mutilado e miserável pelo resultado da atuação do primeiro: a guerra e suas consequências nefastas para os trabalhadores, associada agora ao nazismo. É o que a "aparência" das imagens em contraposição parece evidenciar.

No entanto, com alguns dados a mais, fornecidos pelos pequenos textos que acompanham as imagens, percebe-se que não se trata exatamente disso; que, embora a nova informação não contradiga ou anule a associação anterior (aristocrata nazista x trabalhador), não confirma a impressão inicial dada pelas aparências e coloca a oposição de interesses de classe em destaque. Nos textos, temos notícia de que o trabalhador perdera sua perna em um acidente, em 1910, - portanto, não na guerra - e que seu auxílio previdenciário foi reduzido, no ano anterior, graças a uma lei proposta pelos nazistas no Reichtag (o Parlamento Nacional).

Assim, podemos ler que não seria "apenas" pela oposição de interesses entre o trio "aristocracia prussiana - nazismo - guerra" e os trabalhadores que estes não deveriam aderir ao partido nacional-socialista; seria, essencialmente, porque há uma contradição entre o discurso social nazista (apregoado em diversas publicações ilustradas) e sua prática concreta pró-capitalista (negada por estes publicamente). O apoio do aristocrata ao partido seria uma evidência dessa contradição.

Na montagem, a passagem entre a impressão inicial, dada pela visualização da proposição textual em letras grandes e o choque de imagens, e a leitura dos textos cujas informações não confirmam a primeira sensação, parece feita com vistas a provocar uma quebra de expectativa em relação à associação mimética "naturalizada" pela imprensa ilustrada - poderíamos dizer estranhamento? E traz, nesse processo, uma informação reveladora que se propõe a colocar o leitor de modo distanciado - como observador crítico diante da associação de imagens, ou seja, atento às camadas de informação de modo a não se deixar levar pelas primeiras impressões.

A montagem tem, assim, uma função pedagógica tanto em relação aos conteúdos quanto às formas: evidencia ao leitor que não se pode confiar totalmente nem nas fotografias nem nas relações que são estabelecidas entre elas. Essa preocupação formal de gerar um estranhamento pela quebra de expectativa parece relacionar-se com a conformação do "fotojornalismo moderno", que florescia justamente naquele momento, sendo as revistas ilustradas seus principais vetores de circulação. 
Os anos 1920 trouxeram inovações técnicas que revolucionaram a prática fotográfica e a utilização de fotografias na imprensa. Câmeras menores e mais leves - surgiu a Leica -, o filme em rolo e com maior sensibilidade à luz, dentre outras novidades, permitiram o surgimento da fotografia instantânea e, assim, do "fotojornalismo moderno" (FREUND, 1978, p. 102-3). Num primeiro momento, foram valorizadas as imagens "únicas”, sintéticas. Sua grande característica é serem captadas "sem pose" ou em situações "espontâneas", em que as pessoas fotografadas parecem não se dar conta disso, o que foi chamado de "candid-photo".

Por volta do início de 1930, o fotojornalismo passou a valorizar especialmente as "reportagens": as fotografias passaram a ser articuladas em grupos e/ou sequências associadas com textos, nos quais se contava uma "história", sempre com a prerrogativa de estar apresentando a "verdade", como "provariam" as imagens fotográficas. O fotojornalismo moderno, desse modo, transformou a percepção do público, tendo renovado e ampliado o modo de ver e de "conhecer o mundo". Mesmo os pensadores de esquerda entusiastas das novas mídias e tecnologias, como Walter Benjamin (1892-1940) e Bertolt Brecht (18981956), não tardariam, porém, a perceber que a fotografia - por sua aparência mimética da realidade - poderia ser facilmente manipulada e/ou falseada.

A transformação do fotojornalismo em mero objeto de consumo rápido e superficial, portanto mais alienante que informativo, bem como a confusão - pela associação direta, incentivada pela imprensa ilustrada - entre uma fotografia ou reportagem fotográfica e a "realidade" propriamente dita, tornaram-se objeto de análise crítica e combate. Sobretudo às vésperas da queda da República de Weimar - contexto em que Heartfield realizou essa fotomontagem de capa - em que a máquina de propaganda nazista tirava grande proveito dessa aparência mimética da fotografia para construir suas narrativas falseadoras da realidade histórica.

Este artigo analisa as estratégias de embate político e as técnicas de montagem enquanto princípio artístico vanguardista - desenvolvidas na obra de Heartfield para a revista AIZ naquela conjuntura crítica. O objetivo é apresentar algumas de suas montagens e fotomontagens em confronto com publicações fotojornalística e nazistas, para, assim, compreender como suas obras pretendiam desmascarar e se contrapor às construções fotográficas falseadoras ou alienantes da realidade histórica.

A primeira parte analisa a montagem de páginas desenvolvida por Heartfield que se inicia pela capa da AIZ de 1932 acima - Príncipe e Trabalhador num mesmo partido? - e 
A montagem de Heartfield na guerra ideológica às vésperas da ascensão Nazista na Alemanha

Pollyana Ferreira Rosa

encerra-se com a fotomontagem-caricatura Adolf, o super-homem... Buscamos, aqui, enfatizar como o contexto em que a fotomontagem-caricatura se insere na revista aprofunda sua significação e potência comunicativa e expressiva, muito embora a grande maioria dos estudos contemporâneos ${ }^{6}$ atenham-se apenas às fotomontagens enquanto imagens únicas; e analisar algumas das cenas dessa guerra ideológica travada entre as publicações ilustradas da esquerda comunista e do nazismo.

A segunda parte desenvolve a aproximação esboçada na análise das imagens entre a montagem nas obras de Heartfield e do dramaturgo e teórico da arte Bertolt Brecht. Começamos por localizar o debate dentro da esquerda sobre a montagem enquanto princípio artístico de vanguarda para, então, descrever e apontar como as noções brechtianas de quebra de expectativa, estranhamento e distanciamento crítico iluminam a compreensão da montagem desenvolvida por Heartfield na AIZ.

O artigo encerra discutindo, em uma visão mais ampla do processo, como as fotomontagens de Heartfield praticamente ignoraram a ascensão nazista até quase o apagar das luzes da República de Weimar. Provavelmente, como apontaremos, isso se deu em virtude dos laços entre a revista e o Partido Comunista Alemão $(K P D)$ e à submissão, até certo ponto, à tese oficial do "socialfascismo" defendido por este, que entendia ser a socialdemocracia o maior inimigo dos comunistas.

\section{A GUERRA IDEOLÓGICA NAS REVISTAS ILUSTRADAS}

A revista $A I Z^{7}$, cujos laços junto ao $\operatorname{Komintern~}^{8}$ (e Moscou) não eram explicitados ${ }^{9}$, surgira com esse nome em 1925, numa tentativa de ser uma contraposição às revistas ilustradas "burguesas", as grandes portadoras desse fotojornalismo a que se referem Benjamin e Brecht, porém com imagens e histórias criadas por e sobre trabalhadores. Eles próprios eram, por vezes, os fotógrafos, e trabalhavam pela Associação de Fotógrafos Trabalhadores,

\footnotetext{
${ }^{6}$ Uma inspiradora exceção é a pesquisadora estadunidense Maud Lavin, talvez a primeira autora a analisar a necessidade e produtividade da leitura das fotomontagens de Heartfield no contexto da revista, como era consumida. Há, é evidente, uma dificuldade concreta de acesso aos originais, em pouquíssimos casos digitalizados para além das fotomontagens. O próprio artista levava apenas estas a público em suas publicações e exposições da época.

${ }^{7}$ A AIZ teve diversos nomes desde sua fundação, em 1921. Quando passou a ser quinzenal, em 1925, tornou-se, enfim, Arbeiter Illustrierte Zeitung, cuja tiragem chegava a 220 mil exemplares em 1927.

${ }^{8} \mathrm{~A}$ Terceira Internacional, organização de esquerda vinculada ao governo Stalinista da URSS, que mantinha sob controle os partidos comunistas dos países sob sua influência.

${ }^{9}$ A revista oficial do Partido Comunista Alemão (KPD) era Die Rote Fahne (A Bandeira Vermelha).
} 
A montagem de Heartfield na guerra ideológica às vésperas da ascensão Nazista na Alemanha Pollyana Ferreira Rosa

criada por Willi Münzenberg (1889-1940), o publicista do KPD e do Komintern e editor da AIZ. A partir de 1930, Heartfield tornou-se responsável pela montagem das páginas e pela criação de fotomontagens-caricatura de modo regular.

Berlim era, então, a “cidade-jornal”. Se, em 1927, contava com 147 jornais, em 1928 já eram 2.633, entre diários e revistas semanais (FABRIS, 2003, p. 29). Os partidos e grupos de inúmeras colorações políticas tinham representação impressa. O surgimento da técnica da rotogravura em cobre, com a qual a AIZ passou a ser impressa (HERZFELD, 1976, p. 13), permitiu a Heartfield trabalhar com o meio que considerava ideal para divulgar massivamente suas Fotomontagens da História Contemporânea - desenvolvidas em livros e revistas desde o dadaísmo - embora, com esse nome, a partir de 1924. A tiragem de 500 mil exemplares semanais da revista em 1931 “alcançava um público significativo, integrado por operários, funcionários, donas de casa, profissionais liberais, autônomos e jovens, entre outros. Sua distribuição, além da Alemanha, abarcava Tchecoslováquia, Suíça, e Áustria" (FABRIS, 2009, p. 34).

A edição da $A I Z$ de 17 de julho de 1932, cuja capa reproduzia a imagem do príncipe da Prússia e do desempregado de muletas, revela claramente o objetivo de se contrapor a outras revistas ilustradas a partir de um ponto de vista dos trabalhadores. A fotomontagem de Heartfield abordava um tema que era caro aos nazistas: o mascaramento de suas relações com as classes dominantes e a ilusão de que o movimento possuía um caráter socialista. $\mathrm{Na}$ realidade, os nazistas haviam reconquistado financiamento direto de grandes industriais desde $1930^{10}$, quando alcançaram 6 milhões de votos na eleição para o Reichstag. No entanto, negavam enfaticamente tal relação e esforçavam-se em identificar Hitler com os mais pobres e desempregados (ROSENBERG, 2012, p. 185).

Nas publicações nazistas de 1932, como Fatos e mentiras sobre Hitler (10/04/32) e Derrubem o sistema! (07/1932), por exemplo, aparece um patriotismo conservador de raiz

\footnotetext{
${ }^{10}$ Cf. Rosenberg (2012) p. 185. "Nos anos em que os nazis eram fracos e o capital podia dispensá-los, os industriais alemães importaram-se pouco com eles. Mas, quanto Hitler, repentinamente, passou a controlar 6 milhões de votos, os contatos entre o grande capital e a Suástica foram restabelecidos ao nível a que haviam alcançado em 1923. A elite dos grandes industriais e banqueiros proveram as crescentes necessidades financeiras da Casa Marrom (o quartel general nazista). Esse setor da alta burguesia alemã deu boas-vindas à ascensão da ditadura nacional-socialista e preparou-se para aceitar a possibilidade de que os Nazis absorveriam todos os outros partidos da burguesia alemã. A fraseologia socialista usada pelos agitadores nazistas em encontros públicos mal incomodou os capitalistas pró-nazismo. Eles sabiam que era apenas uma encenação para idiotas. O que contava mais era o ímpeto de Hitler em destruir o marxismo e afastar uma revolução bolchevique da Alemanha. Mas, outra seção dos capitalistas alemães, assim como os grandes proprietários, permaneceram pensativos" [tradução nossa].
} 
prussiana, que deseja a volta à Alemanha imperial; a solidariedade de Hitler e dos nazistas com as massas miseráveis e desempregadas; e a negação de ser "escravo" das elites e de receber financiamento dos grandes industriais. Diz a brochura Fatos e mentiras sobre Hitler:

Fome e pobreza reduziram milhões a pessoas que não reconhecem mais sua pátria natal, mas a pobreza fez de Hitler um nazista, e também um socialista, um porta-voz para os desprovidos entre o nosso povo. [...] $O$ estilo de vida de Adolf Hitler é caracterizado pela simplicidade Espartana. [grifos do original $]^{11}$.

Esse tipo de confusão que Hitler propositadamente fazia, ao invocar o "socialismo" junto ao "nacionalismo", ou seja, a defesa de valores imperiais e patrióticos ao lado da preocupação com as classes trabalhadoras (mistificado como "o povo alemão") era uma de suas principais estratégias. Escreveu, ainda em 1934, o historiador Arthur Rosenberg ${ }^{12}$ (18891943) sobre essa tática da propaganda nazista:

Enquanto eles obviamente fracassaram em fazê-lo [atrair massas por meio de seu programa "socialista"] em 1923, na próxima grande crise a afetar a economia e a sociedade os Nazis puderam projetar-se com sucesso para as massas despossuídas, como os verdadeiros socialistas na Alemanha. Os Nazis representaram um papel duplo, aquele que nenhuma das outras organizações racistas [formadas por aristocratas e alta burguesia] na Alemanha poderia representar. [...] Os nazistas [...], apoiando-se em sua propaganda socialista, fizeram um progresso muito mais rápido nos setores depauperados e miseráveis da população. Mas, ao mesmo tempo, a liderança Nazi iria dizer a seus apoiadores financeiros entre os grandes capitalistas qualquer coisa que estes quisessem ouvir. [tradução nossa] (ROSENBERG, 2012, p. 180-1)

É importante registrar que, naquele momento, boa parte da aristocracia fundiária e alguns capitalistas ainda relutavam em apoiar o nazismo, segundo Rosenberg (2012, p. 185), por conta desse caráter "socialista" pregado em comícios e materiais publicitários. Uma das exceções, naquele período de eleições para o Reichstag, era justamente o príncipe August Wilhelm (1887-1949), que se filiara já em 1930. Ainda que uma exceção, a adesão do príncipe da Prússia, como símbolo do militarismo, da tradição e do império, servia muito bem

\footnotetext{
${ }^{11}$ Cf. Tatsachen und Lügen um Hitler - (Fatos e mentiras sobre Hitler). German Propaganda Arquive, Calvin University. Disponível em: 〈http://www.calvin.edu/academic/cas/gpa/tatsachenundluegen.htm>.

${ }^{12}$ Arthur Rosenberg foi historiador e deputado comunista no Reichstag. Atuou no KPD de 1920 a 1927, quando rompeu com o partido e a tese do "socialfascismo". O texto Fascism as a Mass Movement, publicado originalmente em 1934, é uma pouco conhecida, porém, grande contribuição para a compreensão da ascensão fascista na Alemanha e na Itália.
} 
A montagem de Heartfield na guerra ideológica às vésperas da ascensão Nazista na Alemanha Pollyana Ferreira Rosa

à propaganda nazista para as eleições. É dessas contradições que Heartfield parece querer dar conta na montagem de imagens e textos da capa da $A I Z$ de 17 de julho de 1932.

Heartfield parece apontar para o fato de que a mera associação de imagens não levava ao conhecimento da "realidade"; que poderia, pelo contrário, provocar confusão, dado que a fotografia nada mais é que a reprodução de uma aparência da realidade - idêntica, mimética, por vezes informativa, sim; mas não a realidade em si. Essa questão era excepcionalmente relevante pelo fato de que a propaganda nazista se houvera especializado nessas composições de imagens para "narrar" uma versão falseada da história e dos acontecimentos recentes, repletas de apelo emocional e, dentro de sua lógica e forma internas, provocadoras, coerentes e credíveis.

A capa é um prólogo do argumento exposto nas páginas subsequentes. No topo da página 2 (Fig. 2), repete-se a pergunta: “Príncipe e trabalhador em um mesmo partido?”. Um texto em caracteres ainda relativamente grandes denuncia a propaganda nazista: "os Nazis tentam repetidamente propagar a mentira de que defendem os interesses dos trabalhadores. Nunca o partido dos príncipes e milionários poderia cuidar dos interesses dos trabalhadores". E segue com propaganda eleitoral direta, pedindo votos ao que dizia ser o único partido de fato representante dos trabalhadores, o KPD (Partido Comunista Alemão).

Figura 2 - Página 2, AIZ 11, n. 29

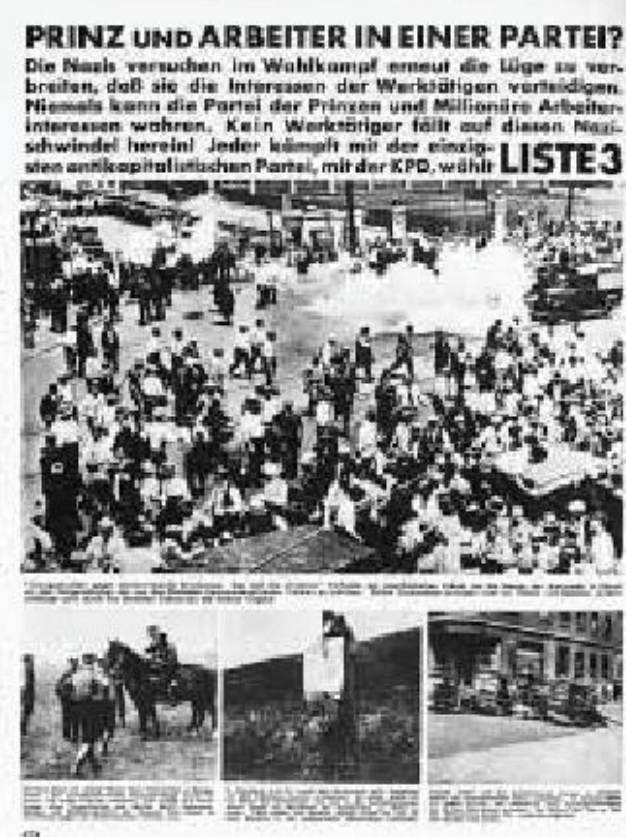

Fonte: LAVIN, 1985, p. 91
Figura 3 - Página 3, AIZ 11, n. 29

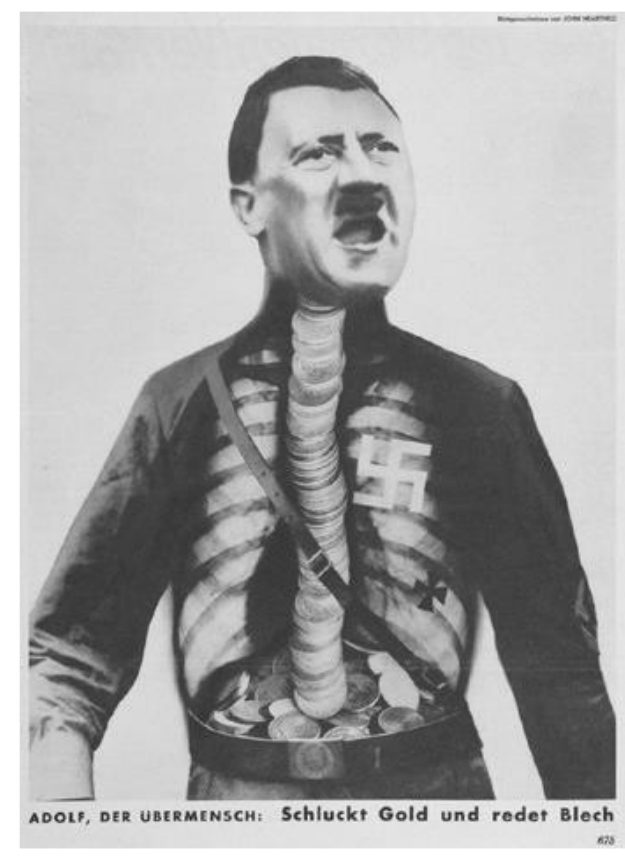

Fonte: HEARTFIELD, 2013, p. 29 
Logo abaixo, ocupando cerca de metade da página, vemos uma foto, cuja legenda diz tratar-se da repressão da polícia de Detroit (EUA) contra uma greve operária. Da relativamente sutil relação vista na capa entre nazistas e o grande capital - dada mais pelos textos - chega-se a uma vinculação direta entre eles. O tema da luta de classes é evidenciado no texto - na contraposição entre príncipe-milionários-nazistas e trabalhadores -, mas principalmente nas fotografias. Heartfield combina uma imagem "clássica" da luta de classes - a repressão política imposta pela polícia (ou seja, pelo Estado) - aos ataques das milícias nazistas a trabalhadores comunistas nas três fotos abaixo, buscando, ao contrário do jogo de imagens da capa, evidenciar suas semelhanças. Em outras palavras: o artista relaciona a repressão política do Estado à violência nazista contra os trabalhadores, no intuito de reforçar a ideia de que o nazismo não pode defender o trabalhador alemão contra o grande capital, pois está ligado a ele.

Na página 3 (Fig. 3), vemos a exposição sintética e cômica desse argumento, que abrirá um texto maior sobre a contradição do discurso "socialista" do nazismo e suas práticas pró-capitalistas (EVANS, 1992, p. 80): a fotomontagem-caricatura Adolf, o super-homem: traga ouro e tagarela disparates [redet Blech, esta última palavra sozinha significa latão, é um chiste].

Nesta fotomontagem, vemos Hitler em enquadramento fechado, com a boca aberta como quem discursa. Em seu torso, como num raio-x (assim Heartfield define, na parte superior direita), revelam-se além das costelas uma pilha de moedas que cai como a linha de sua coluna até o abdômen, onde se acumulam muitas delas. No peito há uma suástica.

Desse modo, o que começou a ser esboçado na capa e desenvolvido na página seguinte, escancara-se sinteticamente na fotomontagem-caricatura: Hitler e os nazistas são fartamente "alimentados" pelas elites capitalistas. O procedimento de montagem evidencia-se pelo teor cômico e absurdo da colagem da cabeça de Hitler num corpo, cujo "raio-X" revela moedas e a suástica. Se as marcas da montagem estão "suturadas", levadas ao obscurecimento, como sugere Bürger (2008), o inverossímil e o cômico a denunciam. E dá-se, então, um novo estranhamento, dessa vez pelo conteúdo cômico: aquele que nega veementemente sua relação com os grandes capitalistas é apresentado ao avesso; ele traga ouro e tagarela disparates para seguir engolfando ouro. Com todas as relações previamente expostas e colocadas em perspectiva de classe, a caricatura de Hitler ridiculariza o locutor e seu discurso como embuste, ao mostrar como ele se sustenta - veja-se a espinha dorsal em 
moedas de ouro. Ao mesmo tempo, no plano formal, a verossimilhança da fotografia é novamente questionada - daí também o estranhamento - quando a fotomontagem revela-se pelo absurdo e cômico visualmente, o que traz a revelação não apenas do conteúdo, mas do caráter "construído" e passível de manipulação da fotografia, portanto, não totalmente confiável enquanto descrição mimética da realidade.

Desse modo, podemos observar que sua técnica utiliza e em seguida expõe o mecanismo pelo qual se pode dirigir a leitura de uma fotografia de modo a alterar sua relação com os fatos. A associação de fotos leva a uma leitura que é esclarecida - ainda que não totalmente falsa - pelos textos e montagens de imagens subsequentes; o caráter construído da fotografia é exposto pela fotomontagem que mantém traços de verossimilhança, a não ser pelo absurdo, pelo choque ou pelo cômico). E, ainda, expõe que se poderia evitar tais falseamentos com uma leitura crítica, distanciada, das imagens.

No contexto de acirrada luta ideológica em plena crise econômica, como veremos, era de extrema relevância explicitar tanto a estratégia das narrativas nazistas criadas por meio de conexões entre fotografias e textos como o uso potencialmente falseador da linguagem fotojornalística em relação à realidade histórica. Não apenas falseadora no sentido de se utilizar de uma fotografia de um acontecimento dizendo tratar-se de outro, o que, sim, era recorrente em inúmeros meios. Mas na própria captação da imagem, na abordagem do fotógrafo com relação ao tema, pautado, naquele momento, pelo mercado de massas e de entretenimento, cujos temas não davam qualquer notícia ao grande público sobre a realidade da crise econômica ou da ascensão fascista.

A partir de 1930, eram inúmeras as publicações ilustradas de entretenimento, jornalísticas e de propaganda nazista que utilizavam-se de articulações de fotografias que complementavam-se e/ou contrastavam-se associadas a textos que dirigiam sua leitura. As fotos supostamente confirmavam, davam credibilidade às narrativas construídas, formando um todo que apresentaria uma "realidade vista por todos os ângulos". Assim, ajudavam a legitimar a interpretação da realidade que a revista trazia. Como dissemos, parece-nos que é para expor tais mecanismos que Heartfield desenvolveu sua montagem com vistas a provocar estranhamentos que tencionarão revelar ao leitor os "truques" realizados com fotografias (a técnica) e as contradições entre discursos e práticas.

Vejamos, a título de ilustração e comparação, duas publicações contemporâneas. A revista ilustrada semanal mais popular na época, voltada ao entretenimento, era a Berliner 
A montagem de Heartfield na guerra ideológica às vésperas da ascensão Nazista na Alemanha Pollyana Ferreira Rosa

Illustrirte Zeitung (BIZ), que chegava à tiragem de 2 milhões de exemplares por semana. $\mathrm{Na}$ edição de 19 de junho de 1932, às vésperas das mesmas eleições parlamentares, a $B I Z$ tematizava o famoso lutador de boxe Max Schmeling (1905-2005). Na capa (Fig. 4), vemos a fotografia de uma luta na qual estão os boxeadores no primeiro plano e a plateia ao fundo. Numa das páginas subsequentes (Fig. 5), a revista expõe, em várias fotos, o treinamento do atleta. Buscava explicitar, segundo a prática fotojornalística da época, "todos os ângulos" - de preferência inusitados, "criativos" - do assunto. As revistas anunciavam que o fotojornalismo e a composição das fotografias eram capazes de mostrar "toda a realidade" de tal ou qual acontecimento. E eram, à época, alvos de críticas pela esquerda alemã, como a de Brecht, citada por Walter Benjamin, e dele próprio, em Pequena História da Fotografia (de 1933):

Na fotografia, ser criador é uma forma de ceder à moda. Sua divisa é: “o mundo é belo". Nela se desmascara a atitude de uma fotografia capaz de realizar infinitas montagens com uma lata de conservas, mas incapaz de compreender um único dos contextos humanos em que ela aparece. Essa fotografia está mais a serviço do valor de venda de suas criações, por mais oníricas que sejam, que a serviço do conhecimento. Mas, se a verdadeira face dessa "criatividade" fotográfica é o reclame ou a associação, sua contrapartida legítima é o desmascaramento ou a construção. Com efeito, diz Bertolt Brecht, a situação "se complica pelo fato de que menos que nunca a simples reprodução da realidade consegue dizer algo sobre a realidade. Uma fotografia das fábricas Krupp ou da AEG não diz quase nada sobre essas instituições. A verdadeira realidade transformou-se em realidade funcional. As relações humanas, reificadas - numa fábrica, por exemplo -, não mais se manifestam. É preciso, pois, construir alguma coisa, algo de artificial, de fabricado" [grifos do autor] (1993, p. 105-6).

Figura 4 - Capa, Berliner Ilustrirte Zeitung

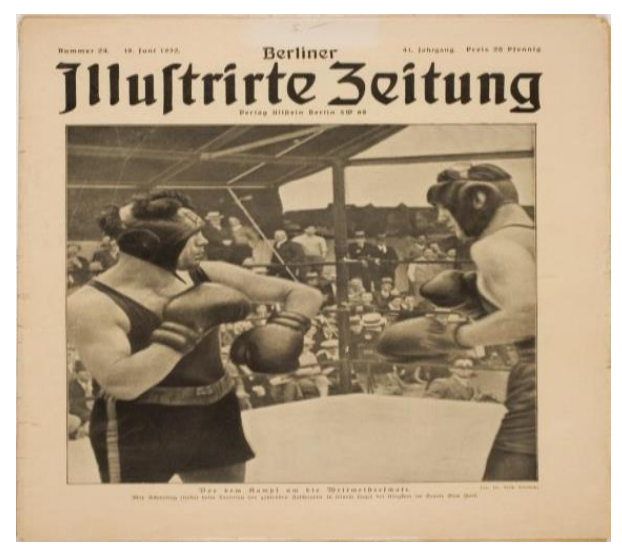

Fonte: Acervo digital do International Center of Photography

<https://www.icp.org/browse/archive/objects/berlinerillustrirte-zeitung>
Figura 5 - Página interna, Berliner Ilustrirte

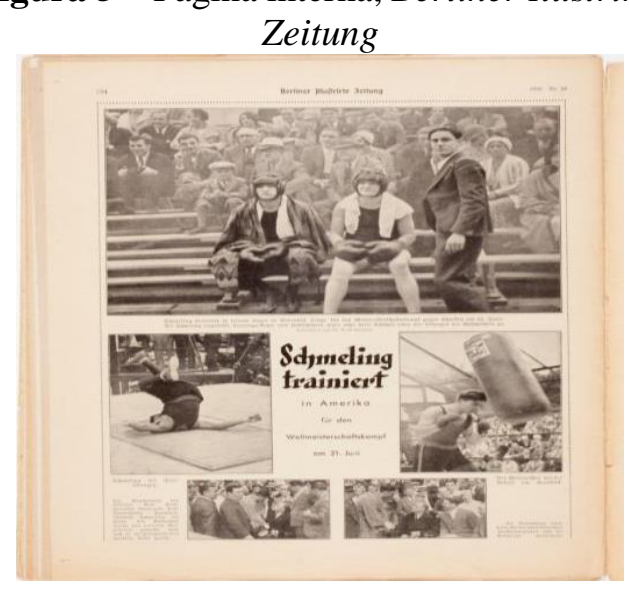

Fonte: Acervo digital do International Center of Photography

<https://www.icp.org/browse/archive/objects/berlinerillustrirte-zeitung> 
É importante, aqui, destacar que Benjamin, evocando Brecht, aposta no "desmascaramento" dessa "falsa realidade" apresentada pela fotografia "criativa" - muito provavelmente referindo-se às revistas e outras publicações ilustradas -, por meio da construção e da montagem. A nosso ver, era precisamente o que Heartfield tencionava com a montagem das páginas e as fotomontagens-caricatura publicadas na AIZ. Com projeto gráfico vanguardista, a revista era composta por diversos conteúdos: artigos sobre política nacional e internacional, temas de "interesse humano", reportagens fotográficas feitas por trabalhadores, romances publicados em capítulos, poesia, páginas dedicadas à mulher ou à criança, piadas, palavras cruzadas e uma página destinada a produções artísticas, a cargo de Heartfield, ilustrada por colaboradoras como Tina Modotti (1896-1942) e Käthe Kollwitz (1867-1945).

Brecht recomendou a revista em 1931: "A câmera pode mentir tanto quanto uma máquina de escrever. A missão da $A I Z$ de servir a verdade e reproduzir os fatos reais é de imensa importância e, ao que me parece, foi alcançada esplendidamente" (EVANS, 1992, p. 11). Naquele contexto, Münzenberg já houvera compreendido o impacto das revistas ilustradas e seu poder de persuasão das massas, tendo escrito que "uma revista ilustrada é mais divertida que um artigo de vanguarda em um diário político" (EVANS, 1992, p. 11). Era-lhe claro que seria mais viável alcançar um grande público por meio de uma revista ilustrada do que por um jornal de teoria marxista tradicional.

Entretanto, Joseph Goebbels (1897-1945) também já se dera conta do potencial de influência sobre as massas que ofereciam as revistas ilustradas. Além de sua própria publicação, o Illustrierte Beobachter (Observador Ilustrado), lançada em 1926, as revistas ou brochuras de campanhas eleitorais de Hitler também traziam combinações de imagens e construção de argumentos por meio de sequências. Vejamos Derrubem o sistema!, lançada, assim como a edição a $A I Z$ a que nos referimos, em julho de 1932. É notável como há aproximações com parte da crítica ao sistema feita pela esquerda - inclusive ao governo social-democrata. 


\section{Figura 6 - Capa, Derrubem o sistema!}

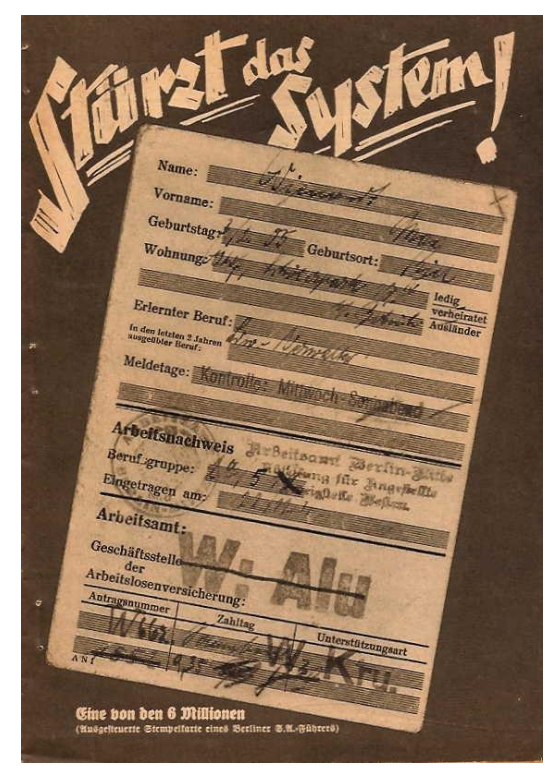

Fonte: German Propaganda Arquive - Calvin University <http://research.calvin.edu/german-propaganda-archive/stuerzt-das-system.htm>

A brochura de 32 páginas traz na capa, junto ao título Derrubem o sistema!, a fotografia do cartão de desempregado de um dos líderes nazistas (Fig. 6). E inicia-se com a identificação do sistema a ser derrubado: a República, proclamada durante a Revolução de novembro de 1918. Fazendo uma espécie de retrospectiva, a publicação, por meio da articulação de imagens fotojornalísticas e pequenos textos, relaciona à República de Weimar todos os problemas sociais - em especial a inflação, a fome e o desemprego -, e a uma suposta "traição" dos "verdadeiros valores germânicos" por comunistas e judeus ${ }^{13}$.

A revista também responde às críticas dos "marxistas" atacando-os como "falsos socialistas" - pois que eram contra o nacionalismo e, portanto, contra os interesses do "povo germânico". E, por fim, expõe qual seria a solução: Adolf Hitler, apresentado em diversas fotografias em sequência como um homem simples e dedicado ao "povo".

Analisemos nas páginas 10-11 e na sequência 22-24 parte da construção do argumento ao longo das páginas. Chama a atenção, na página 10 (Fig. 7), uma fotografia de dentro de um cofre de um grande banco, com pilhas e mais pilhas de dinheiro. Os nazistas buscavam aqui apresentar sua versão para a enorme inflação que afligia sobretudo a enorme

\footnotetext{
${ }^{13}$ Essa perspectiva de apontar os Comunistas enquanto os responsáveis pela derrota na $1^{\text {a }}$ Guerra Mundial é um mito que foi amplamente difundido desde os primeiros anos da República de Weimar, como uma forma de tentar justificar a humilhação sofrida pelo governo imperialista prussiano. Os nazistas não o criaram, mas bem souberam utilizá-lo em seu proveito.
} 
população desempregada. “O sistema causa a inflação!”, diz o título, complementado por uma tabela em que aparecem os números do aumento da inflação na Alemanha desde 1918, explicando-a de maneira convincente, no contexto, porém obviamente simplista (seria causada apenas pela impressão desenfreada de cédulas de dinheiro para alimentar a ambição das elites).

Figura 7 - Página 10, Derrubem o sistema!

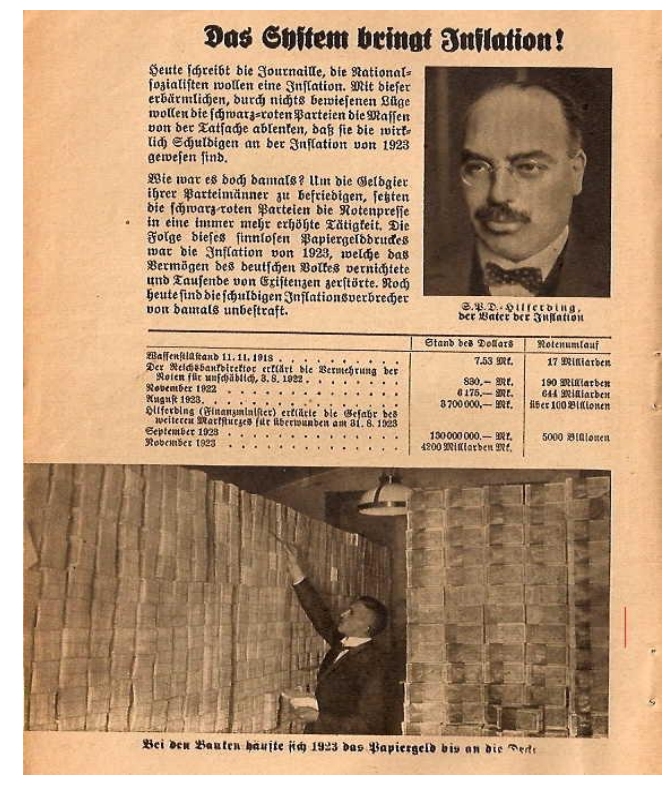

Fonte: German Propaganda Arquive - Calvin University

$<$ http://research.calvin.edu/german-propagandaarchive/stuerzt-das-system.htm>
Figura 8 - Página 11, Derrubem o sistema!

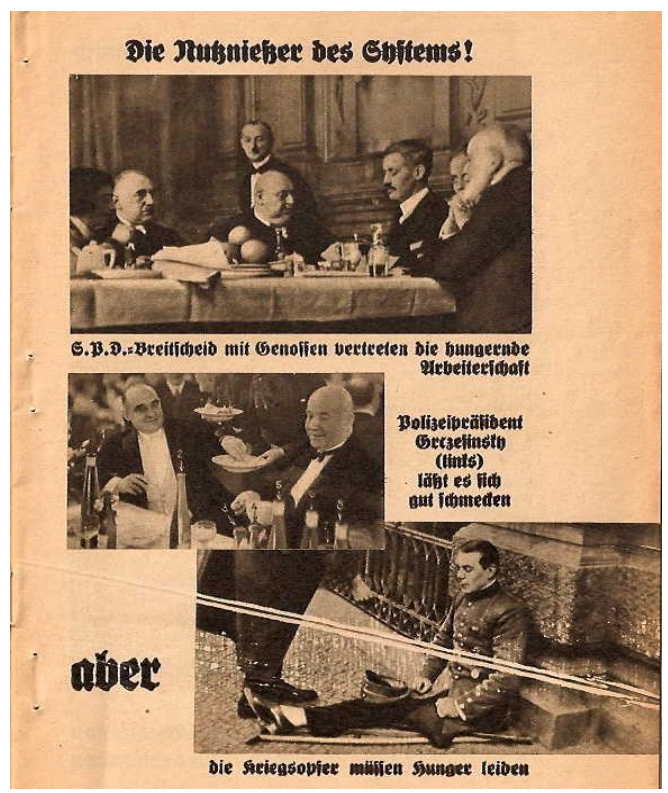

Fonte: German Propaganda Arquive - Calvin University

$<$ http://research.calvin.edu/german-propagandaarchive/stuerzt-das-system.htm>

Na página 11 (Fig. 8), que descrevia os "beneficiários do sistema", vemos duas fotografias de jantares luxuosos, nos quais aparecem políticos do SPD e o presidente da polícia, Grezesinsky. Logo abaixo delas, há um veterano de guerra, de muletas, a pedir esmolas numa calçada. A imagem vem acompanhada dos dizeres: "Breitscheid, do SPD, com companheiros. Eles representam trabalhadores famintos. O presidente da polícia Grezesinsky (à esquerda), aprecia uma boa refeição. Mas veteranos de guerra têm de passar fome.”

Algumas páginas à frente, vemos acusações aos judeus de serem responsáveis pela exploração do povo e pela quebra dos negócios de pequenos comerciantes durante a crise pós1929. A página 22 (Fig. 9) faz a contraposição de fotografias de uma grande loja de departamentos, alegadamente propriedade de um judeu, e pequenas lojas de bairro de portas fechadas. Acompanha as fotos, a frase: “O sistema tolera que lojas de departamentos judias 
explorem o povo, enquanto os pequenos comerciantes, cujos negócios frequentemente duraram gerações, são arruinados.”

Figura 9 - Página 22,

Derrubem o sistema!

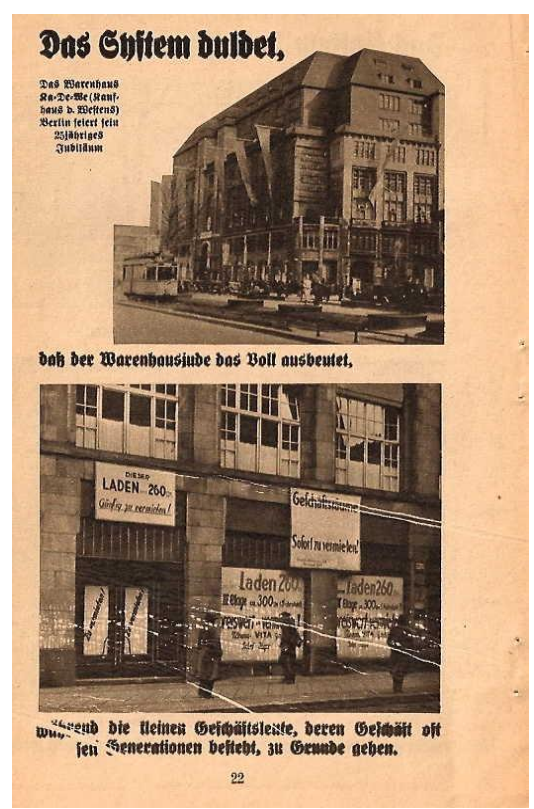

Fonte: German Propaganda Arquive - Calvin University $<$ http://research.calvin.edu/germanpropaganda-archive/stuerzt-dassystem.htm>
Figura 10 - Página 23,

Derrubem o sistema!

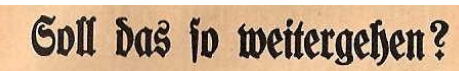

Rein!

Dies Snjtem muß

gejtiitzt werden!

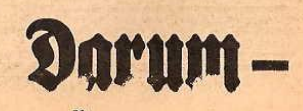

Fonte: German Propaganda Arquive - Calvin University $<$ http://research.calvin.edu/german -propaganda-archive/stuerzt-dassystem.htm>
Figura 11 - Página 24,

Derrubem o sistema!

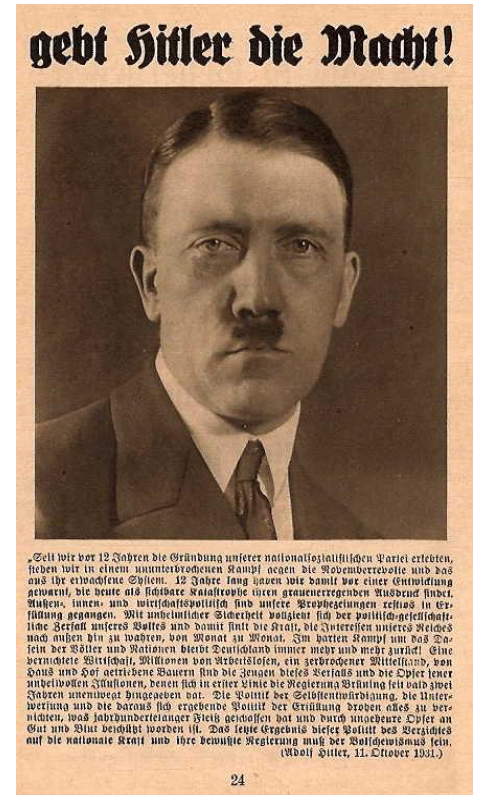

Fonte: German Propaganda

Arquive - Calvin University $<$ http://research.calvin.edu/german -propaganda-archive/stuerzt-dassystem.htm>

A página seguinte (Fig. 10) traz, em caracteres góticos enormes (identificados com a estética tradicional germânica), o texto: "Deve isso continuar? Não! O Sistema deve cair! Portanto". Vira-se a página, e vê-se uma foto de Hitler, que ocupa mais da metade da página 24 (Fig. 11), a encarar o leitor, com os dizeres: "Dê poder a Hitler", seguida de imagens “carismáticas" do líder nazista entre o povo. O panfleto encerra-se sob o argumento de que o nacional-socialismo seria o único movimento capaz de solucionar os problemas do "povo alemão" faminto e desempregado no campo e na cidade. Diz: "Nacional-socialismo traz trabalho e pão" (Fig. 12), numa composição visual de palavras e fotos de chaminés industriais combinadas com cenas de trabalho rural. 
Figura 12 - Páginas 30-1, Derrubem o sistema!

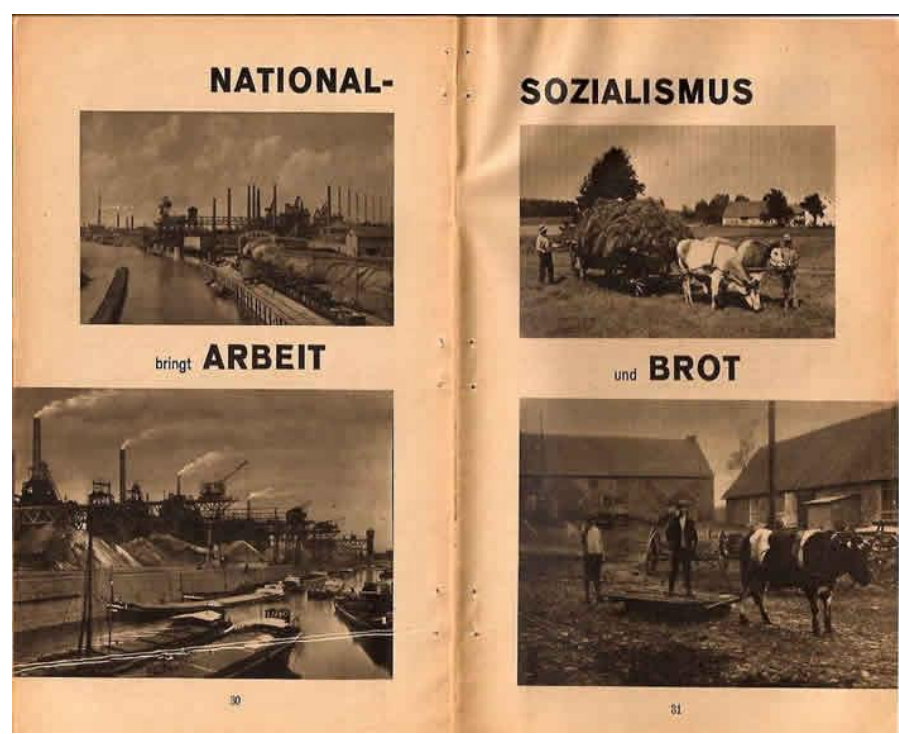

Fonte: German Propaganda Arquive - Calvin University <http://research.calvin.edu/german-propaganda-archive/stuerzt-das-system.htm>

Parece-nos provável que Heartfield e Münzenberg tentassem - ainda que, naquele contexto crítico, tardiamente - responder a essa publicação nazista com a edição da $A I Z$ de 17 de julho de 1932.

Se observarmos essas publicações da época, $B I Z, A I Z$ e aquelas nazistas, percebemos muitas similaridades. Porém há, a nosso ver, ao menos duas diferenças marcantes, para além do conteúdo: apenas na revista AIZ há uma construção tal como a "fotomontagem-caricatura" como parte da articulação visual vanguardista e, ao mesmo tempo, como elemento de estranhamento; e apenas nesta revista é possível identificar a utilização de contraposições de fotografias - tanto em termos de conteúdos como de formas - tendo em vista expor uma perspectiva de classe e, ao mesmo tempo, os "truques" para falseamento da realidade utilizados naqueles tempos.

\section{UMA APROXIMAÇÃO ENTRE AS MONTAGENS EM HEARTFIELD E BRECHT}

A partir das vanguardas históricas do início do século XX, o princípio artístico da montagem e a problemática da autonomia da arte têm lugar central nos debates críticos e nos desenvolvimentos artísticos das mais diversas linguagens (literatura, cinema, artes visuais etc.). Benjamin, Brecht e, posteriormente, Peter Bürger (1936-2017), colocaram-se nesses 
debates em defesa da experimentação do princípio da montagem (contra Gyorgy Lukács 1895-1971) e contra a autonomia da arte (contra Theodor Adorno - 1903-1969), que deveria passar a ter função social de crítica da ideologia. Como desenvolvimentos artísticos dentro dessa perspectiva, temos os estudos teóricos, a dramaturgia (e encenação) e o cinema de Brecht, e a montagem de Heartfield, cuja aproximação parece-nos ser produtiva para a compreensão das obras de ambos os autores bem como do processo histórico e artístico em que estavam inseridos.

Nesse sentido, conforme viemos testando e esboçando até aqui, propomos a utilização dos conceitos criados/desenvolvidos por Brecht - "estranhamento" e "distanciamento", provocados por "quebras de expectativa" -, para iluminar e compreender aspectos relevantes da prática artística da montagem de Heartfield para além das fotomontagens-caricatura. Atenhamo-nos a eles, por alguns instantes.

Os princípios de "estranhamento" para criar um "distanciamento crítico" estão de alguma forma presentes na obra de Brecht ao menos desde 1926-27, embora suas definições teóricas tenham sido escritas apenas a partir dos anos 1930. As proposições épicas do dramaturgo precisam ser lidas no contexto da crise do drama e da defesa do teatro épico como linguagem mais apropriada para lidar com os "novos assuntos" que o processo histórico exigia. O drama, desde o final do século XIX, adotara as características do romance: tramas que se desenvolvem linearmente rumo a um desenlace no final, incentivo à empatia catártica do espectador, ação que diz respeito à vida privada e dilemas "psicologizados" e resolvidos em termos de caráter das personagens e da imutabilidade do mundo, por exemplo. $\mathrm{O}$ teatro épico já em desenvolvimento por Erwin Piscator (1893-1966) buscava justamente colocar questões de ordem social e política propondo soluções como a introdução de elementos "extra-dramáticos" em cena, como a narração, abolida pelo drama burguês.

Brecht, no ensaio $O$ assunto e a forma, publicado em 1929, ponderou que não bastava trazer "novos assuntos" ao drama, mas que estes deveriam ser adequados a explorar as "novas relações entre os homens". Para tanto, seria necessário primeiro compreender esses "novos assuntos" (o petróleo, p.ex.) para, então, "modelar as novas relações" (BRECHT, 1967, p. 47). As formas tradicionais do drama, porém, não possuíam "ferramentas" adequadas para tais necessidades. Impunha-se, assim, o desenvolvimento de novas formas, que deveriam ter um novo objetivo: a pedagogia. 
No ano seguinte, Brecht fez uma reflexão sobre a transformação do teatro em mercadoria - que promove uma diversão alienante - e do papel das "grandes engrenagens" na orientação da criação artística. Segundo seu diagnóstico, toda "inovação" no drama seria permitida apenas na condição de não ameaçar o próprio sistema, colocando os artistas como meros fornecedores de mercadorias culturais (BRECHT, 1967, p. 55). Desse modo, as formas tradicionais, transformadas em mercadorias, modernizadas, porém, ainda inadequadas para dar conta das novas questões relevantes que se colocavam, prestavam-se apenas à manutenção do sistema que os aprisionava enquanto artistas e à alienação social.

As inovações de linguagem propostas por Brecht consistiam na subversão ou inversão das formas, técnicas e objetivos da forma dramática tradicional, sem perder de vista o caráter divertido do espetáculo. A famosa tabela que contrapõe teatro épico e dramático apresenta tanto estratégias técnicas para o manejo do assunto e estrutura formal (construção articulada, saltos/interrupções, narração, pensamento e ações humanas determinadas pela posição social, não como questão de caráter), como os objetivos dessas técnicas: fazer do espectador um observador distanciado, que é levado a analisar as situações colocadas e tomar decisões sobre elas. E sem abrir mão da diversão. Ao que nos parece, as noções de "estranhamento", “distanciamento crítico" estão já aqui esboçadas por Brecht.

Desse modo, o efeito de estranhamento deveria operar por meio de diversas possibilidades de quebras de expectativa e novas abordagens artísticas dadas aos assuntos (a criação de novas formas para os novos conteúdos). E essas novas formas deveriam mais que apenas contrariar ou subverter as figurações tradicionais; elas deveriam colocar tais assuntos em perspectiva de classe (reveladores do modus operandi do capitalismo). O objetivo seria colocar o espectador-observador de modo crítico e distanciado diante das questões e relações trabalhadas de modo dialético pela montagem, cuidando que ele possa rir e se divertir nesse processo. Não por acaso, o cômico está muito presente em toda a obra brechtiana.

Em outro texto chamado Efeito de estranhamento nas imagens narrativas de Brueghel, o Velho, escrito por volta de 1934, Brecht (1964, p. 157) nos dá um exemplo desse "efeito" a partir de uma imagem. Trata-se de uma análise de A queda de Ícaro (Fig. 13) e o modo como o artista maneja contradições. Embora o "tema" seja a queda do personagem mitológico, este não está em evidência. É uma cena idílica, que nada apresenta da tragédia que a queda representaria. 
No primeiro plano vemos um camponês a arar a terra, um pouco adiante outro homem pesca, ao fundo vemos o mar e navios e montanhas. Onde está Ícaro? Apenas suas pernas desajeitadas e algumas penas das asas aparecem, num canto da imagem. Todos os outros personagens do quadro estão de costas para ele. Eis um exemplo de estranhamento, que, a nosso ver (concordando com Brecht), apresenta um tom claramente cômico ao ser construído por meio de uma espécie de "inversão de prioridades" - de uma quebra de expectativa - em relação ao que seria uma figuração "correta", dentro da tradição, de um tema mitológico, apresentando a vida dos camponeses como mais interessante que o malfadado personagem mítico Ícaro. Brecht observa como as imagens de Brueghel, o velho (1525-1569) podem ser cômicas e trágicas ao mesmo tempo: "sua tragédia contém um elemento cômico e sua comédia é trágica".

Figura 13 - Brueghel, o velho. A queda de Ícaro, c. 1558

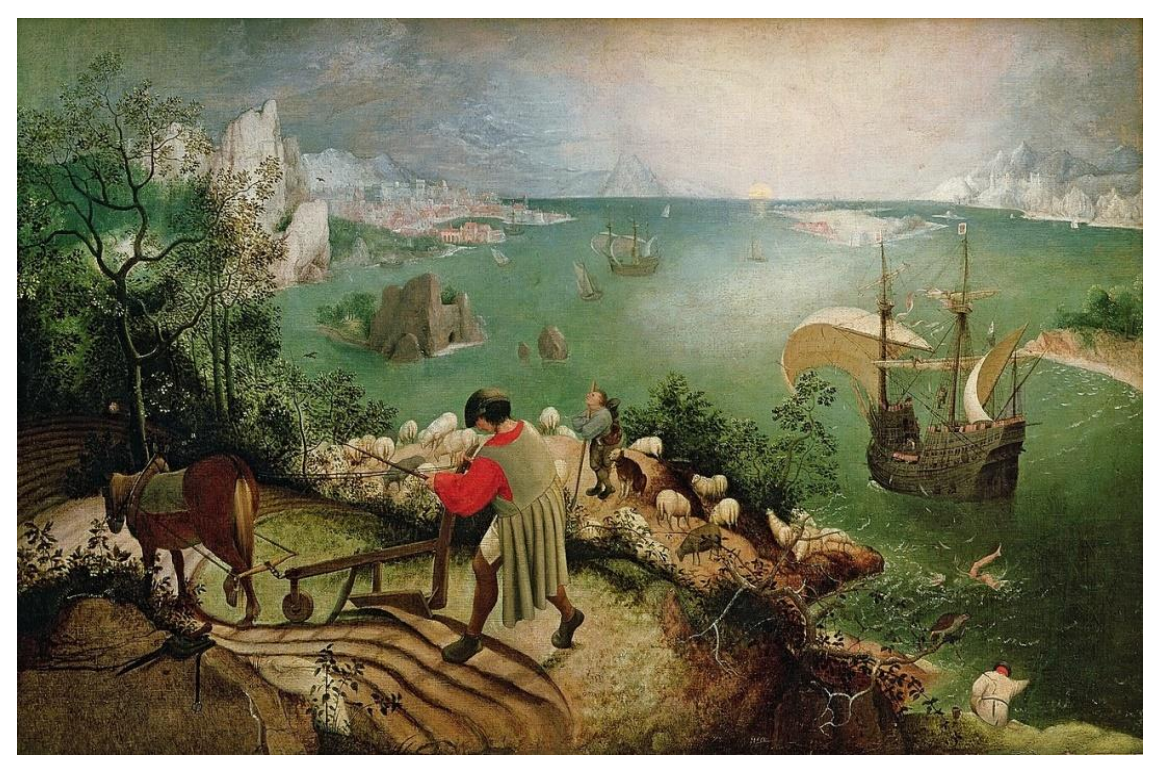

Fonte: Wikimedia. <https://upload.wikimedia.org/wikipedia/commons/thumb/c/c2/Pieter_Bruegel_de_Oude__De_val_van_Icarus.jpg/1280px-Pieter_Bruegel_de_Oude_-_De_val_van_Icarus.jpg $>$

Entendemos, diante do exposto, que Heartfield trabalhava segundo princípio semelhante de montagem em sua respectiva linguagem, e que, portanto, as noções de estranhamento e distanciamento criados por meio de quebras de expectativa, em perspectiva de classe e com vistas a produzir também divertimento são apropriadas e produtivas para a análise e compreensão da obra do artista gráfico alemão. Ou seja, de forma similar ao Teatro Épico de Brecht, as montagens e fotomontagens-caricatura de Heartfield contrapõem-se às formas-mercadoria das associações de imagens do fotojornalismo (e seu grande potencial para 
falsear ou manipular a compreensão da realidade) e o caráter de "diversão alienante" nas revistas da nascente indústria cultural e, nas nazistas, de "politização alienante".

\section{A ASCENSÃO DO NACIONAL-SOCIALISMO E A ESTRATÉGIA POLÍTICA EQUIVOCADA DA $A I Z$}

Embora boa parte das imagens mais conhecidas de Heartfield sejam lidas como "armas" de uma "guerra durante a paz" contra Hitler, esse combate só começou às vésperas da ascensão do nazismo e a maioria das fotomontagens-caricatura mais conhecidas em nossos dias foram publicadas na Alemanha, à época, apenas de forma clandestina e em tiragem reduzida drasticamente em relação aos anos anteriores. Portanto, sua atuação deu-se mais no âmbito da luta contra o fascismo na Europa pré-guerra, mas com bastantes menos exemplares em circulação, até às vésperas do pacto de não-agressão entre Hitler e Stalin - o que encerrou a publicação ilustrada pois provocou o rompimento de Münzenberg com Moscou.

A própria revista $A I Z$ começou a levar realmente a sério o risco de uma hegemonia nazista apenas em 1932, bem depois das primeiras vitórias eleitorais relevantes do partido nacional-socialista (NSDAP) para o Reichtag (1930). Ainda assim, bem antes da burocracia comunista, como veremos.

Desde que Heartfield iniciou sua parceria com a $A I Z$, o principal foco de ataques da revista fora o Partido Social Democrata $(S P D)$ e o governo do chanceler católico Heinrich Brüning (1885-1970, chanceler de 30 de março de 1930 a 30 de maio de 1932) - aliás, assim como faziam as publicações do nacional-socialismo. Para darmos uma ideia, nesse primeiro ano, das 11 fotomontagens publicadas, seis eram contra o SPD, duas delas equiparando a socialdemocracia ao nazismo. Uma única imagem, publicada logo após a conquista, pelo partido nazista, dos mais de 6 milhões de votos para o Reichstag, vinculava o grande capital ao movimento fascista. $\mathrm{O}$ ano seguinte, boa parte do qual Heartfield passou em viagem à URSS e sem fazer contribuições à revista, não trouxe qualquer referência direta ao nazismo. Três das quatro fotomontagens publicadas em 1931 são acusações contra políticos do SPD e sua proximidade com a aristocracia militar e a burguesia.

Essa curiosa omissão no enfrentamento ao nazismo estava de acordo com a avaliação política oficial do Komintern e do KPD, que afirmava não haver diferença entre o nazismo e a socialdemocracia - cujo partido, o SPD, fazia parte do governo de Brüning - e chamava-os todos de "socialfascistas". Essa tese argumentava, surpreendentemente, que o maior inimigo 
dos trabalhadores era o SPD. Não que fosse tarefa fácil compreender os acontecimentos naqueles anos de crise, de modo que questionar a política socialdemocrata era coerente com a realidade e respaldável à esquerda e à direita. Pois que Brüning, desde setembro de 1930, após a conquista, pelos nazistas, de 107 das 608 cadeiras do Reichstag, houvera imposto um estado de sítio: passara a governar por decretos, independente da Assembleia, suspendera os direitos civis e impusera duras medidas de austeridade diante da gravíssima crise econômica iniciada em 1929 que, por sua vez, promoveram um desemprego galopante. No pior período da depressão, 1932-3, 44\% dos trabalhadores alemães não conseguia emprego. O governo, portanto, era acusado pelos nazistas de corrupto e extravagante e de obstaculizar a ascensão do "povo" ao poder - a sua própria, evidente - e, pelos comunistas ligados ao KPD, de ser "socialfascista". Essa avaliação da conjuntura estava longe de ser consenso na esquerda, especialmente entre os não alinhados ao stalinismo. Segundo Hobsbawn (1995, p. 108), apenas em 1934 o KPD e o Komintern mudariam de posição frente ao nazismo.

Diante disso, outros autores de perspectiva à esquerda produziram duras críticas às posturas do KPD e à teoria do socialfascismo. Leon Trotsky (1879-1940), já em oposição aos rumos da URSS sob Stalin, por exemplo, defendia que a confusão conceitual entre o regime ditatorial de Brüning e o que poderia advir com o nazismo, perspectiva de fato fascista, servia apenas para facilitar a ascensão nacional-socialista. Escreveu ele no início de 1932:]

O fascismo não é simplesmente um sistema de repressão, atos de força e de terror policial. O fascismo é um sistema de Estado particular, baseado na exterminação de todos os elementos da democracia proletária na sociedade burguesa. A tarefa do fascismo não consiste somente em destruir a vanguarda proletária, mas também em manter toda a classe num estado de fragmentação forçada. [...] A social-democracia preparou todas as condições para a vitória do fascismo. Mas preparou também as condições de sua própria liquidação política. Lançar-se sobre a social-democracia a responsabilidade do sistema de decretos-lei de Brüning e da barbárie fascista ameaçadora é inteiramente justo. Identificar-se a social-democracia com o fascismo é inteiramente insensato (TROTSKY, 1979, p. 139-40). 
Figura 14 - Caricatura do panfleto A maldita suástica: Algo para se pensar

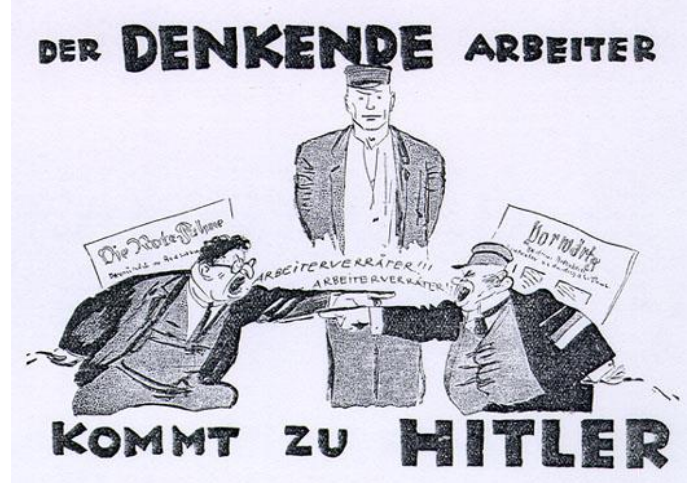

Fonte: German Propaganda Arquive - Calvin University $\langle$ http://research.calvin.edu/german-propaganda-archive/haken32.htm>

Fato é que os nazistas buscaram tanto provocar como tirar proveito dessa nefasta confusão (decorrente daquela sobre os "verdadeiros socialistas"), como se pode observar numa caricatura publicada no panfleto A maldita suástica: Algo para se pensar, escrito por Goebbels em pessoa, amplamente impresso e divulgado a partir de 1929. Nela, vemos na parte inferior, políticos do KDP e do SPD e seus respectivos jornais - Die Rote Fahne e Vorwärtz - acusando-se mutuamente de "traidores dos trabalhadores". Um trabalhador de olhar sério que se coloca acima daquele imbróglio ridículo está pronto a escolher seguir com Hitler. Diz o texto: “Trabalhador que pensa vem para Hitler” (Fig. 14).

Também o economista contemporâneo Alfred Sohn-Rethel fez críticas à estratégia de propaganda comunista contra o nazismo. Para ele, esta também acabou por colaborar com a grande confusão reinante no campo político, derivada das próprias contradições do nazismo e da inabilidade do KPD:

Com sua estratégia [do Partido Nacional-Socialista] de propaganda de massas e com o crescimento contínuo de seus sucessos eleitorais, Hitler tomou a iniciativa na luta pelo poder político. Sob essa pressão, a executiva do Partido Comunista permitiu-se ser ludibriada e entrar em uma batalha com as mesmas armas, mas, para eles, as erradas, de partido de massas e eleitoral, e foi isto que custou-lhe a real chance de revolução. Porque pelo fato de o partido fascista se caracterizar por um excêntrico relacionamento com a sociedade burguesa [ataque público a ela, apoio privado dela], emergiu a rivalidade na propaganda entre o $N S D A P$ e o $K P D[\ldots]$ que tanto confundiu o campo político àquela época. [...] A propaganda nazista pintou as fraquezas e infortúnios, as contradições e doenças da sociedade burguesa com as tintas mais escuras possíveis. A propaganda comunista fez o mesmo. Ambas frequentemente fizeram soar o mesmo trompete, entraram pelo mesmo sulco, derramaram sua bílis política nas mesmas feridas e apenas competiram para ver qual deles o faziam mais alto e impetuosamente. E, 
mais frequentemente, foi o Angriff [ataque] de Goebbels que venceu sobre a Rote Fahne [Bandeira Vermelha, revista oficial do KPD]. É claro que seus jargões anticapitalistas - os genuínos dos comunistas e os falsos dos nazis eram mundos à parte: conceitos de classe no primeiro, conceitos raciais no outro. [...] Os argumentos econômicos eram para os nazistas apenas um pretexto; para os comunistas eles eram coisas da realidade. Mas apesar disso, os comunistas nunca exploraram totalmente o potencial de seus argumentos econômicos [tradução nossa] (SOHN-RETHEL, 1978, p. 132-3).

Na realidade, até as vésperas das eleições de julho de 1932, Heartfield tratava do nazismo com certo desprezo, como uma força no máximo risível, que não representava ameaça séria (aliás, como parte considerável da esquerda e de artistas). A partir de então, há uma mudança na estratégia: das 18 fotomontagens publicadas em 1932, na $A I Z$, seis são ataques diretos ao nazismo e a Hitler, das quais duas fazem a vinculação entre o nacionalsocialismo e o grande capital. Outras três tratam do capitalismo e/ou imperialismo e a guerra, enquanto apenas uma faz ataque ao SPD. É notável como, nas fotomontagens, a relação militarismo-nazismo-grande capital enquanto inimigos de classe será explorada de forma crescente, transformando-se em um dos principais temas de Heartfield após a ascensão do nazismo ao poder, no início de 1933.

Outra das imagens que marcam essa virada é $O$ verdadeiro sentido da saudação de Hitler, publicada em 16 de outubro de 1932 (Fig. 15), também às vésperas de novas eleições para o Reichstag, nas quais os nazistas perderam cerca de 2 milhões de votos em relação às de julho. Talvez seja a fotomontagem-caricatura mais clara, objetiva e engraçada a tratar da ligação entre grande capital e o nazismo desde o início da colaboração entre Heartfield e a AIZ. E é a terceira fotomontagem seguida a zombar de Hitler desde Adolfo super-homem...

Figura 15 - O verdadeiro sentido da saudação de Hitler, AIZ 11, n.42

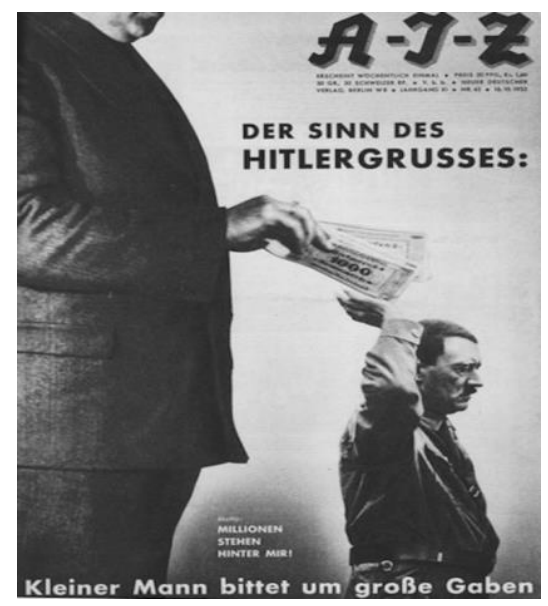

Fonte: HEARTFIELD, 2013, p. 39. 
Nessa fotomontagem-caricatura, vemos, à esquerda, um homem em tamanho desproporcionalmente maior que Hitler, que aparece no canto inferior. Este enorme corpo em trajes civis, que ostenta um anel com um enorme diamante mas não tem face, dispõe milhões em notas sobre a mão levantada de Hitler, em saudação característica. O texto completa o argumento: "O verdadeiro sentido da saudação de Hitler: o pequeno homem exige grandes presentes". Entre a representação do "grande capital" e a figura miniaturizada de Hitler, um pequeno texto ridiculariza o brado repetido pelo nazista desde seus primeiros 6 milhões de votos: "Motto: milhões estão atrás de mim!". Com esse "estranhamento" cômico, Heartfield deixa explícito tanto que o movimento nazista é financiado pelos grandes capitalistas, como o fato destes serem, portanto, os principais beneficiários da ascensão do nacional-socialismo.

\section{CONSIDERAÇÕES FINAIS}

O fotojornalismo moderno que floresceu nos anos finais da República de Weimar e circulava em massa por meio de revistas ilustradas criou novas possibilidades de se "conhecer o mundo" vendendo "a realidade por todos os ângulos". Intelectuais de esquerda não tardaram a perceber que essa ilusão de verdade criada pela aparência mimética da fotografia estava sendo utilizada para o falseamento e a manipulação da realidade - sobretudo quando articulada com textos e outras fotos, como se tornara usual. Nesse contexto, não bastasse a alienação promovida pelo fotojornalismo mercantilizado como entretenimento superficial, os nazistas bem souberam tirar proveito dessa característica da imagem fotográfica para dar credibilidade a suas narrativas falseadoras da realidade.

Diante disso, no âmbito dos debates e experimentações formais com o princípio artístico da montagem, Heartfield desenvolveu sua técnica no sentido de expor que a mera associação de imagens não levava ao conhecimento da "realidade", mas, antes, era uma forma de apresentá-la, uma construção que poderia ganhar sentidos diferentes a depender do contexto em que se encontrava articulada. Nesse sentido, criou tanto as mais conhecidas e estudadas fotomontagens-caricatura, - que desafiam a credibilidade da imagem fotográfica pelo cômico e absurdo, e ainda são divertidas; como as também sofisticadas montagens de páginas da revista $A I Z$, em que os jogos de imagens e textos criam, em sentido brechtiano, quebras de expectativas no intuito de gerar e estranhamentos e distanciamento crítico em 
relação à imagem fotográfica e suas composições, sem perder de vista a diversão e a perspectiva de classe.

Parece-nos, portanto, deveras interessante a apropriação da teoria do Teatro Épico de Brecht como "iluminadora" para a compreensão da montagem em Heartfield, sobretudo em seu aspecto ainda pouco estudado da montagem de páginas em articulação com as fotomontagens-caricatura, que ganham, assim, maior profundidade de significação e expressão.

Entretanto, é preciso observar que se o diagnóstico e a estratégia de Heartfield de contraposição e desmascaramento das características potencialmente ilusórias e manipuláveis do fotojornalismo parecem apropriados para lidar com a propaganda ilustrada nazista, fica evidente que esse combate começou demasiado tarde para ter chance de obter algum sucesso.

Desse modo, temos que, por conta de um grave erro de leitura e avaliação da conjuntura alemã da burocracia comunista ligada a Moscou, perdeu-se o timing, a possibilidade de realmente intervir na luta contra o fascismo na Alemanha. Isso deixa evidente que há certo equívoco na leitura corrente e generalizante sobre a obra e atuação do artista naquele contexto. Tal constatação abre, portanto, caminho para pesquisas acerca da circulação e potencial impacto da revista e da obra de Heartfield nos e pelas mãos dos grupos de resistência interna e nos movimentos antifascistas/pacifistas dos anos 30 ao redor do mundo.

Parece-nos, enfim, de grande interesse na atualidade o desenvolvimento de novos estudos em torno dessa guerra ideológica contra o nazismo, de modo geral e em relação com outras mídias de impacto social à época; e, especialmente no campo da História e Teoria da Arte, de pesquisas com foco nas montagens de Heartfield produzidas para a AIZ para além da fotomontagem-caricatura enquanto imagem única.

\section{REFERÊNCIAS}

BENJAMIN, Walter. Magia e Técnica, Arte e Política. São Paulo: Brasiliense, 1993.

BRECHT, Bertolt. Teatro Dialético. Rio de Janeiro: Civilização Brasileira, 1967.

Brecht on theatre - The development of an Aesthetic. Edited \& translated by John

Willet. New York: Hill and Wang, 1964.

BÜRGER, Peter. Teoria Da Vanguarda. São Paulo: Cosac Naify, 2008. 
EVANS, David. John Heartfield, AIZ: Arbeiter-Illustriete Zeitung, Volks Illustrierte, 19301938. New York, NY, U.S.A: Kent, 1992.

FABRIS, Annateresa. Fotografia e Arredores. Florianópolis: Letras Contemporâneas, 2009. 2003. . "A fotomontagem como função política" in: História, v. 22, n. 1. São Paulo: UNESP,

FREUND, Gisele. La Fotografia como Documento Social. Barcelona: Editorial Gustavo Gili, 1976.

HEARTFIELD, John. John Heartfield: Fotomontagens / John Heartfield: Photomontages. São Paulo: Imprensa Oficial do Estado de São Paulo; Museu Lasar Segall, 2013. 1976. \& HERZFELDE, Wieland. Guerra en la Paz. Barcelona: Editorial Gustavo Gili,

HOBSBAWN, Eric. A Era dos Extremos - O Breve Século XX - 1914-1991. São Paulo: Companhia das Letras, 1995.

LAVIN, Maud. "Heartfield in Context" in Art in America, New York, v. 73, $n^{\circ} 2$ (Feb, 1985): pp. 85-93.

ROSENBERG, Arthur. "Fascism as a Mass-Movement (1934)" in Historical Materialism 20, $n^{o} 1$ (Jan 1, 2012): pp. 144-189. doi: 10.1163/156920612X634898.

SOHN-RETHEL, Alfred. Economy and class structure of German fascism. London: CSE Books, 1978.

SOUSA, Jorge Pedro. Uma História Crítica do Fotojornalismo Ocidental. Florianópolis: Letras Contemporâneas, 2004.

TROTSKY, Leon. Revolução e Contra-revolução na Alemanha. Tradução de Mário Pedrosa. São Paulo: Ciências Humanas, 1979. 